\title{
Pendampingan Implementasi Aplikasi Sistem Informasi Akuntansi pada UMKM di Desa Kerinjing, Ogan Ilir, Sumatera Selatan
}

\author{
Arista Hakiki ${ }^{1}$, Yusnaini ${ }^{1 *}$ dan Nur Khamisah ${ }^{1}$ \\ ${ }^{1}$ Fakultas Ekonomi, Universitas Sriwijaya, Sumatera Selatan, Indonesia \\ *Email korespondensi: yusnaini@fe.unsri.ac.id; Phone: +628127851034
}

Info Artikel: Diterima: 05 Juni 2021; Disetujui: 24 September 2021; Dipublikasi: 05 November 2021

\begin{abstract}
Abstrak: Sistem Informasi Akuntansi dapat digunakan pada semua jenis dan skala usaha, baik skala besar maupun Usaha Mikro Kecil dan Menengah (UMKM). Namun fakta dan data di lapangan menunjukkan bahwa sebagian besar UMKM dan Bumdes beranggapan sistem informasi akuntansi belum diperlukan dalam mengelola usaha bisnis bahkan terkesan mahal dan kompleks. Dari fenomena tersebut dianggap perlunya pendampingan implementasi aplikasi sistem informasi akuntansi untuk UMKM. Pendampingan tersebut diharapkan dapat memberikan solusi permasalahan terkait pemanfaatan aplikasi sistem informasi akuntansi UMKM khususnya di Desa Kerinjing. Adapun peserta dari kegiatan pendampingan ini dari kelompok UMKM dan BUMDES Desa Kerinjing. Pendampingan dilakukan dengan pemberian penjelasan tentang pentingnya pemrosesan transaksi untuk UMKM sebagai dasar untuk menyusun laporan keuangan. Selanjutnya diperkenalkan aplikasi software yang sudah dirancang khusus untuk pemrosesan transaksi. Aplikasi berbasis Microsoft Excel ini dirancang sangat sederhana. Pengguna hanya perlu mencatat dan mengentry transaksi terkait penerimaan dan pengeluaran kas. Dalam kegiatan pendampingan ini juga dilakukan demo penggunaan aplikasi software dilanjutkan dengan penggunaan langsung aplikasi oleh perwakilan UMKM dan BUMDES dengan arahan dari instruktur tim pengabdian kepada masyarakat FE UNSRI. Peserta diberikan waktu untuk mencoba aplikasi dengan memasukkan beberapa transaksi rutin penerimaan dan pengeluaran kas. Dengan demikian warga pelaku UMKM dan Bumdes dapat memahami dengan lebih jelas hal-hal yang masih belum dimengerti. Tim pengabdian juga memberikan software yang berisi aplikasi sederhana dalam pelaporan keuangan yang dapat dimanfaatkan oleh warga Desa Kerinjing khususnya pelaku UMKM dan Bumdes.
\end{abstract}

Kata Kunci: UMKM; Sistem Informasi Akuntansi; Laporan keuangan

\section{Kutipan:}

Hakiki, A., Yusnaini, \& Khamisah, N. (2021). Pendampingan Implementasi Aplikasi Sistem Informasi Akuntansi pada UMKM di Desa Kerinjing, Ogan Ilir, Sumatera Selatan. Sricommerce: Journal of Sriwijaya Community Services, 2(2): 125-132. DOI: https://doi.org/10.29259/jscs.v2i2.64

\section{PENDAHULUAN}

Dalam kurun waktu dua dekade terakhir ini setidaknya sudah terjadi dua kali krisis ekonomi global yang membuat beberapa perusahaan besar dunia mengalami kebangkrutan. Terakhir, krisis global di tahun 2008 yang menyebabkan General Motor (GM), salah satu perusahaan otomotif terbesar di Amerika mengalami kebangkrutan. Sebelumnya, krisis ekonomi dan keuangan di Amerika juga pernah terjadi akibat masalah pembiayaan perusahaan property. Di Indonesia sendiri, krisis ekonomi dan keuangan yang berat juga pernah terjadi di tahun 1998 dan 2008. Banyak perusahaan yang terpaksa melakukan pemecatan karyawan, pemotongan harga barang 
dan jasa hingga bangkrut secara keseluruhan akibat krisis ekonomi dan keuangan global tersebut.

Fakta menarik muncul pada masa krisis tersebut ternyata banyak perusahaan yang tergolong Usaha Mikro Kecil Menengah (UMKM) yang tetap bisa bertahan sementara sebagian besar perusahaan besar menyatakan kebangkrutannya. Fenomena tersebut menunjukkan bahwa kebangkrutan sebagai akibat krisis global tidak melihat besar kecilnya perusahaan. Menjadi sangat menarik untuk dilihat bagaimana peran dan keberadaan system informasi akuntansi dibalik kemampuan UMKM bisa bertahan sekalipun dalam situasi krisis. Jumlah Usaha Mikro Kecil dan Menengan (UMKM) di Indonesia merupakan kelompok usaha yang memiliki jumlah yang paling besar tetapi perkembangan usaha UMKM tidak begitu pesat. Berdasarkan Informasi pada Berita Musi, jumlah UMKM di Palembang saat ini mencapai 36.101 UMKM yang tersebar di setiap kecamatan (4/2/2016). Selain jumlahnya yang sangat banyak UMKM juga mempunyai potensi bisnis untuk berkembang lebih baik dengan dukungan system informasi akuntansi.

Sistem Informasi Akuntansi dapat digunakan pada semua jenis dan skala usaha, baik skala besar maupun Usaha Mikro Kecil dan Menengah (UMKM). UMKM merupakan kegiatan usaha yang berperan dalam proses peningkatan pendapatan, pertumbuhan ekonomi, serta mewujudkan stabilitas nasional. Meskipun UMKM telah menunjukkan peranannya dalam perekonomian nasional, namun UMKM masih menghadapi berbagai hambatan dan kendala, baik yang bersifat internal maupun eksternal. Salah satu hambatan yang paling mendominasi adalah mengenai permodalan (Farhan et.al., 2020).

Pada tanggal 19 Mei 2009, Dewan Standar Akuntansi Keuangan (DSAK) mengesahkan Standar Akuntansi Keuangan untuk Entitas tanpa Akuntabilitas Publik (SAK ETAP). Standar Akuntansi Keuangan untuk Entitas Tanpa Akuntabilitas Publik (SAK ETAP) adalah standar akuntansi yang disusun sebagai acuan dan dimaksudkan untuk digunakan entitas tanpa akuntabilitas publik yang dimaksudkan agar semua unit usaha menyusun laporan keuangan sesuai dengan standar yang telah ditetapkan, sehingga diharapkan UMKM dapat menyusun laporan keuangan secara sederhana namun terstandar dan dapat menjadi diacuan bagi kreditor untuk meminjamkan dana.

Kehadiran teknologi informasi diharapkan dapat meningkatkan kinerja usaha dengan menghasilkan informasi yang akurat, tepat waktu dan dapat diandalkan. Menurut Hubeis (2009) Faktor umum yang mempengaruhi kegagalan usaha kecil yaitu: Manajerial yang tidak kompeten, kurang member perhatian, Sistem kontrol yang lemah dan kurangnya modal. Hasil penelitian Muhindo at all (2014), menunjukkan bahwa banyak bisnis kecil yang tidak menerapkan sistem informasi akuntansi sehingga mengakibatkan kinerja bisnis tersebut rendah. Almilia dan Briliantien (2007) mengemukakan bahwa keberhasilan SIA dapat diukur dari kinerja sistem tersebut dalam perusahaan karena baik buruknya kinerja sebuah Sistem Informasi Akuntansi akan menentukan kepuasan dari pemakai dan pemakaian sistem informasi itu sendiri. Kinerja SIA yang baik mampu memenuhi kebutuhan pemakai sistem informasi, sehingga dapat membantu pemakai sistem menyelesaikan pekerjaannya (Srimindarti, 2012).

Kinerja suatu sistem informasi akuntansi baik atau tidak harus diketahui ukuran efektivitas kinerja sistem informasi akuntansi. Ukuran efektivitas kinerja sistem informasi akuntansi dapat dilihat melalui dua pendekatan yaitu kepuasan pemakai informasi dan pemakaian SIA oleh pegawai pada bagian keuangan dalam membantu menyelesaikan pekerjaannya mengolah data keuangan menjadi informasi akuntansi (Almilia, 2007). Kinerja sistem informasi akuntansi yang baik akan membantu mempermudah pekerjaan pemakai sistem informasi akuntansi serta meningkatkan efisiensi dan efektifitas. Hasil dari SIA berupa informasi yang dihasilkan oleh pengguna sistem informasi akuntansi ini dapat membantu manajemen dalam proses perencanaan strategi bisnis dan pengambilan keputusan guna mencapai tujuan perusahaan. Keberadaan sistem informasi akuntansi berkualitas memerlukan proses pengembangan secara terus menerus sesuai dengan perkembangan dan pertumbuhan perusahaan dan lingkungannya (Hakiki et.al., 2020).

Dengan demikian keberadaan sistem informasi akuntansi sangat penting bagi semua jenis dan level usaha bisnis. Sistem informasi akuntansi juga dapat diterapkan untuk semua jenis usaha termasuk UMKM. Fakta dan data di lapangan menunjukkan bahwa sebagian besar UMKM dan Bumdes beranggapan system informasi akuntansi belum diperlukan dalam mengelola usaha bisnis bahkan terkesan mahal dan kompleks. Atas dasar itulah diperlukan pendampingan implementasi 
aplikasi system informasi akuntansi untuk UMKM. Diharapkan pendampingan ini dapat memberikan solusi permasalahan terkait pemanfaatan aplikasi system informasi akuntansi UMKM khususnya di Desa Kerinjing.

\section{STUDI PUSTAKA}

\subsection{Sistem Informasi Akuntansi}

Akuntansi sebagai bahasa bisnis diartikan sebagai penghubung antara organisasi bisnis yang ada dengan para stakeholder, baik internal maupun eksternal (Josua, 2010). Dari perspektif akuntansi keuangan, fungsi akuntansi selama ini memang lebih banyak fokus kepada pelaporan kondisi keuangan organisasi pada suatu saat tertentu dan perubahan kondisi keuangan organisasi dalam periode waktu tertentu. Padahal sebenarnya akuntansi memiliki peranan yang jauh lebih penting dari sekedar compliance drivers, yaitu sebagai alat analisis yang bisa menjadi value drivers bagi organisasi perusahaan (Josua, 2010). Sebagai alat analisis, akuntansi keuangan berfungsi sebagai horizontal analysis yang memungkinkan organisasi perusahaan melakukan perbandingan laporan keuangan dalam beberapa tahun sehingga tren setiap akun dapat dilihat dan dianalisis.

Secara filosofi, fungsi akuntansi keuangan sangatlah penting dalam suatu organisasi perusahaan baik secara informal maupun secara formal. Perkembangan dan variasi model bisnis yang semakin kompleks sekarang membuat keberadaan akuntansi keuangan semakin dibutuhkan. Dyer dan McHugh (1975) menyatakan bahwa ketepatan waktu penyampaian laporan keuangan merupakan salah satu karakteris penting bagi laporan keuangan yang merupakan produk utama akuntansi keuangan. Banyak pihak yang memiliki kepentingan terhadap laporan keuangan sehingga penyusunan laporan keuangan harus dilakukan secara wajar, dapat dipercaya dan tidak ada unsur penipuan bagi penggunanya. Untuk memberikan jaminan kewajaran informasi yang disajikan dalam laporan keuangan tersebut maka penyusunan laporan keuangan harus memenuhi ketentuan dalam Standar Akuntansi Keuangan (SAK).

Sistem informasi akuntansi merupakan sistem yang mengolah data akuntansi untuk menyediakan informasi yang dibutuhkan oleh pemakai internal dan eksternal perusahaan. Pemakai internal meliputi pengurus perusahaan dan pekerja sedangkan pemakai eksternal meliputi pemegang saham, pihak pemerintah, investor, bank dan pemberi pinjaman. Pemakai informasi akuntansi tersebut mengharapkan informasi yang berkualitas yang dapat digunakan untuk pembuatan keputusan penting berkaitan dengan perusahaan. Informasi yang berkualitas ini hanya dapat dihasilkan dari sistem informasi akuntansi yang berkualitas.

Pertumbuhan dan pengembangan organisasi perusahaan saat ini sangat dipengaruhi oleh setiap perubahan teknologi informasi dan telekomunikasi. Perkembangan teknologi informasi yang sangat cepat telah memberi pengaruh yang besar terhadap sistem informasi perusahaan. Untuk menghadapi perubahan itu, banyak perusahaan yang telah memberikan perhatian yang serius dan bersungguh-sungguh terhadap kewujudan sistem informasi perusahaan terutama sistem informasi akuntansi yang telah diyakini sebagai penyedia informasi utama bagi sistem informasi manajemen untuk pembuatan keputusan (Apriani, et.al., 2021).

\subsection{Pengembangan Sistem Informasi Akuntansi}

Menurut Romney, et. al. (2009), beberapa faktor yang menyebabkan perusahaan melakukan perbaikan sistem informasi didiantaranya adalah perubahan kebutuhan bisnis atau pemakai, perubahan teknologi, peningkatan proses bisnis, keunggulan persaingan, keunggulan produktivitas, pertumbuhan, downsizing, dan peningkatan kualitas. Faktor tersebut menggambarkan pengaruh perubahan lingkungan terhadap pertumbuhan perusahaan dan tentunya terhadap sistem informasi perusahaan. Hal ini didukung pula oleh Gelinas, et. al. (2012) yang menyatakan bahawa organisasi perusahaan wujud dalam lingkungan yang dinamis. Oleh itu, perubahan dan pengembangan sistem informasi perusahaan terutama sistem informasi akuntansi dipengaruhi oleh beberapa aspek perubahan lingkungan perusahaan tersebut, diantaranya kebutuhan undang-undang seperti pelaporan pemerintah, tingkat dan jenis persaingan, teknologi yang digunakan untuk memproses informasi seperti alat pemasukan data, garis bisnis atau jenis 
aktivitas bisnis, dan keinginan manajemen untuk mengakses informasi lebih baik dan meningkatkan laporan manajemen. Pandangan kedua pakar tersebut menggambarkan pengaruh faktor internal dan eksternal perusahaan terhadap perubahan kepentingan akan sistem informasi perusahaan.

Pengembangan sistem informasi akuntansi sangat penting bagi meningkatkan kualitas informasi akuntansi sesuatu perusahaan. Hal ini bertambah penting dengan semakin meningkatnya kebutuhan akan informasi akuntansi oleh para pemakai baik pemakai internal ataupun eksternal perusahaan dalam menghadapi perubahan lingkungan yang sangat dinamis. Keberhasilan proses pengembangannya dipengaruhi oleh banyak faktor.

Siklus pengembangan sistem informasi merupakan sesuatu proses perubahan sistem secara sebagian ataupun secara menyeluruh, tujuannya adalah untuk memperbaiki kualitas informasi, meningkatkan efisiensi sistem informasi dan memperbaiki kualitas pengendalian internal. Secara umum ada tiga tahap utama dalam proses pengembangan sistem informasi, iaitu tahap analisis, reka bentuk dan pelaksanaan. Tahap analisis bertujuan mengidentifikasi masalah yang ada pada sistem yang sedia ada dan mencoba mencari beberapa alternatif pemecahan masalah yang mungkin dilakukan. Tahap analisis ini sangat penting karena hasil tahap analisis akan mempengaruhi tahap perancangan dan pelaksanaan sistem. Aktivitas utama dalam tahap perancangan adalah merancang alternatif yang dipilih untuk memecahkan masalah yang meliputi perancangan proses dan prosedur, masukan dan pengendalian. Tahap akhir proses pengembangan sistem informasi adalah pelaksanaan sistem baru.

Menurut Gelinas, et. al. (2012), beberapa faktor yang mempengaruhi keberhasilan pengembangan sistem informasi adalah : dukungan top manajemen, perbedaan kebutuhan pemakai, pengembangan strategi sistem, teknologi baru, proyek manajemen dan metode pengembangan sistem yang standard, staf pengembangan yang terlatih, partisipasi pemakai, pengujian yang tepat, dan latihan pemakai. Menurut Stair (2009), proses pengembangan sistem informasi juga mesti didukung oleh tim pengembangan sistem informasi. Tim pengembangan sistem informasi harus memahami objektif, visi dan misi sebuah perusahaan untuk keberhasilan pengembangan sistem informasi. Pemahaman ini dapat membawa kepada proses perancangan dan reka bentuk sistem yang sesuai dengan kebutuhan manajemen perusahaan. Pandangan ini didukung pula oleh Romney, et.al. (2013) yang menyatakan bahawa tim pengembangan sistem informasi akuntansi memiliki peranan yang penting dalam merancang, memantau dan mengkomunikasikan proses pengembangan sistem kepada semua pemakai.

\subsection{Pengertian Dan Kriteria Usaha Mikro, Kecil dan Menengah}

Berdasarkan Undang-Undang Republik Indonesia Nomor 20 Tahun 2008 Tentang Usaha Mikro, Kecil, dan Menengah, definisi UMKM yaitu:

1. Usaha Mikro adalah usaha produktif milik orang perorangan dan/atau badan usaha perorangan yang memenuhi kriteria Usaha Mikro.

2. Usaha Kecil adalah usaha ekonomi produktif yang berdiri sendiri, yang dilakukan oleh orang perorangan atau badan usaha yang bukan merupakan anak perusahaan atau bukan cabang perusahaan yang dimiliki, dikuasai, atau menjadi bagian baik langsung maupun tidak langsung dari Usaha Menengah atau Usaha Besar.

3. Usaha Menengah adalah usaha ekonomi produktif yang berdiri sendiri, yang dilakukan oleh orang perorangan atau badan usaha yang bukan merupakan anak perusahaan atau cabang perusahaan yang dimiliki, dikuasai, atau menjadi bagian baik langsung maupun tidak langsung dengan Usaha Kecil atau Usaha Besar.

Berdasarkan Undang-Undang Republik Indonesia Nomor 20 Tahun 2008 Tentang Usaha Mikro, Kecil, dan Menengah, kriteria UMKM yaitu:

1. Kriteria Usaha Mikro adalah sebagai berikut:

a. memiliki kekayaan bersih paling banyak Rp50.000.000,00 (lima puluh juta rupiah) tidak termasuk tanah dan bangunan tempat usaha; atau

b. memiliki hasil penjualan tahunan paling banyak Rp300.000.000,00 (tiga ratus juta rupiah). 
2. Kriteria Usaha Kecil adalah sebagai berikut:

a. memiliki kekayaan bersih lebih dari Rp50.000.000,00 (lima puluh juta rupiah) sampai dengan paling banyak Rp500.000.000,00 (lima ratus juta rupiah) tidak termasuk tanah dan bangunan tempat usaha; atau

b. memiliki hasil penjualan tahunan lebih dari Rp300.000.000,00 (tiga ratus juta rupiah) sampai dengan paling banyak Rp2.500.000.000,00 (dua milyar lima ratus juta rupiah).

3. Kriteria Usaha Menengah adalah sebagai berikut:

a. memiliki kekayaan bersih lebih dari Rp500.000.000,00 (lima ratus juta rupiah) sampai dengan paling banyak Rp10.000.000.000,00 (sepuluh milyar rupiah) tidak termasuk tanah dan bangunan tempat usaha; atau

b. memiliki hasil penjualan tahunan lebih dari Rp2.500.000.000,00 (dua milyar lima ratus juta rupiah) sampai dengan paling banyak Rp50.000.000.000,00 (lima puluh milyar rupiah).

\subsection{Akuntansi Untuk Usaha Mikro Kecil dan Menengah}

Ikatan Akuntan Indonesia telah menerbitkan Standar Akuntansi Keuangan untuk Entitas Tanpa Akuntabilitas Publik (SAK-ETAP). Standar ini dimaksudkan untuk digunakan oleh entitas tanpa akuntabilitas publik. Entitas tanpa akuntabilitas publik yang dimaksud adalah entitas yang tidak memiliki akuntabilitas publik signifikan dan menerbitkan laporan keuangan untuk tujuan umum bagi pengguna eksternal. Standar Akuntansi Keuangan untuk Entitas Tanpa Akuntabilitas Publik (SAK-ETAP) dimaksudkan untuk digunakan oleh entitas kecil dan menengah. Entitas kecil dan menengah adalah entitas yang yang menenuhi kriteria (a) tidak memiliki akuntabilitas publik yang signifikan; atau (b) berdasarkan peraturan perundang-undangan digolongkan sebagai entitas kecil dan menengah; dan menerbitkan laporan keuangan untuk tujuan umum (general purpose financial statement) kepada pengguna eksternal. Contoh pengguna eksternal termasuk pemilik yang tidak terlibat langsung dalam pengelolaan usaha, kreditor, dan lembaga pemeringkat kredit.

\section{METODE}

Adapun peserta dari kegiatan pendampingan ini dari kelompok UMKM dan BUMDES Desa Kerinjing. Pendampingan dilakukan dengan pemberian penjelasan tentang pentingnya pemrosesan transaksi untuk UMKM sebagai dasar untuk menyusun laporan keuangan. Selanjutnya diperkenalkan aplikasi software yang sudah dirancang khusus untuk pemrosesan transaksi. Aplikasi berbasis Microsoft Excel ini dirancang sangat sederhana. Pengguna hanya perlu mencatat dan mengentry transaksi terkait penerimaan dan pengeluaran kas. Pemrosesan transaksi kas menjadi dasar untuk pemrosesan jenis laporan lain sesuai kebutuhan, antara lain laporan laba rugi, laporan asset dan posisi keuangan (neraca).

Dalam kegiatan pendampingan ini juga dilakukan demo penggunaan aplikasi software dilanjutkan dengan penggunaan langsung aplikasi oleh perwakilan UMKM dan BUMDES dengan arahan dari instruktur tim pengabdian kepada masyarakat FE UNSRI. Penggunan mencoba aplikasi dengan memasukkan beberapa transaksi rutin penerimaan dan pengeluaran kas. Pendampingan diakhiri dengan serah terima aplikasi software dalam bentuk flashdisk kepada Sekretaris Desa Kerinjing.

\section{HASIL DAN PEMBAHASAN}

Pengabdian masyarakat Pelatihan Pendampingan Implementasi Aplikasi Sistem Informasi Akuntansi pada UMKM dan Bumdes di Desa Kerinjing, Ogan Ilir, Sumatera Selatan . Kegiatan pengabdian diadakan pada hari Kamis, 14 November 2019, kegiatan tersebut dilaksanakan di salah satu kediaman aparatur desa Kerinjing. Pada saat pelaksanaan pertama kali disambut baik oleh warga dengan penuh antusias warga menerima kedatangan tim pengabdian Fakultas Ekonomi Universitas Sriwijaya dengan harapan akan memperoleh ilmu yang bermanfaat untuk kemajuan Desa, kemudian tim dipersilahkan untuk mengambil posisi yang telah warga sediakan. 

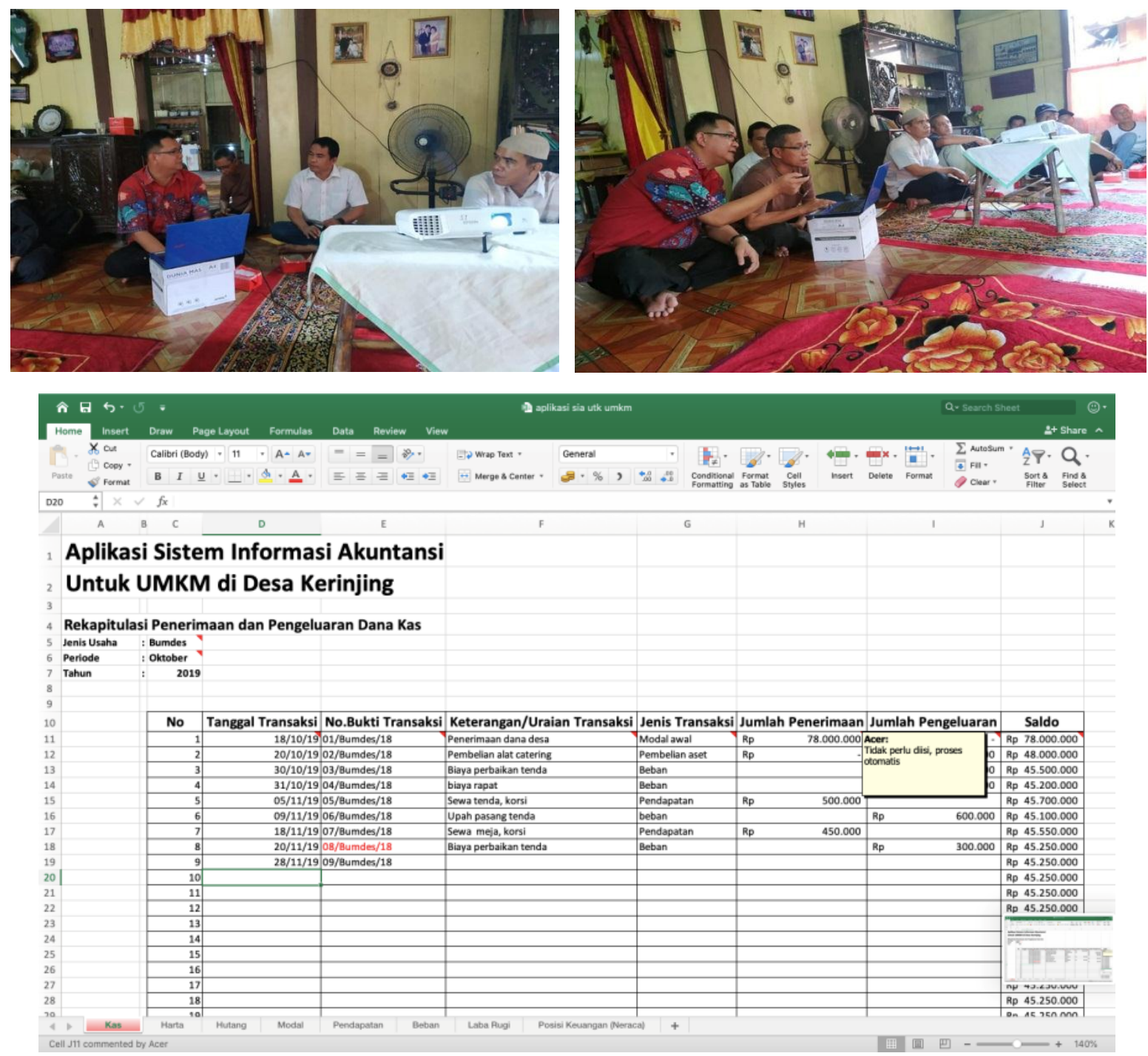

Gambar 1. Paparan Materi Aplikasi Sederhana Pelaporan Keuangan dan Demo Aplikasi Software

Sebelum acara inti dimulai terlebih dahulu dilaksanakan proses pembukaan oleh perangkat desa. Selanjutnya acara dimulai dengan sambutan-sambutan dari Kepala Desa dan Ketua Pelaksana Pengabdian yang dalam hal ini diwakilkan oleh Drs. Burhanuddin, M.Acc, Ak. CA. Setelah kata sambutan dilanjutkan dengan menyiapkan peralatan seperti pemasangan spanduk dan menyiapkan proyektor/LCD untuk persiapan pemaparan serta pembagian materi kepada warga yang hadir pada kegiatan tersebut. Materi dalam pengabdian ini disampaikan oleh Arista Hakiki, SE., M.Acc., Ak., pada saat pemamparan materi warga terlihat focus memperhatikan pemaparan, untuk menambah pemahaman warga diberikan handout slide powerpoint yang di paparkan. Pemaparan berlangsung selama kurang lebih 15 menit kemudian dilanjutkan dengan sesi diskusi berkaitan dengan permasalah yang selama ini di hadapi warga terkait implemetasi laporan keuangan dan sistem informasi akuntansi dalam kegiatan operasional UMKM warga desa Kerinjing.

Disksusi awal dimulai dari pengajuan pertanyaan-pertanyaan dari warga pelaku UMKM dan Bumdes yang berkaitan dengan perlunya pelaporan keuangan, pengetahuan yang memadai terkait pelaporan keuangan, implementasi penggunaan aplikasi sistem informasi akuntansi yang disajikan serta beberapa pertanyaan terkait logika-logika pencatatan akuntansi yang tepat untuk beberapa transaksi yang terjadi pada UMKM dan Bumdes warga. Pertanyaan-pertanyaan yang muncul tersebut dijadikan sebagai bahan untuk diskusi lanjutan,pertanyaan tersebut dijawab oleh tim pengabdian Bpk. Arista Hakiki dan bu Yusnaini (foto terlampir). 


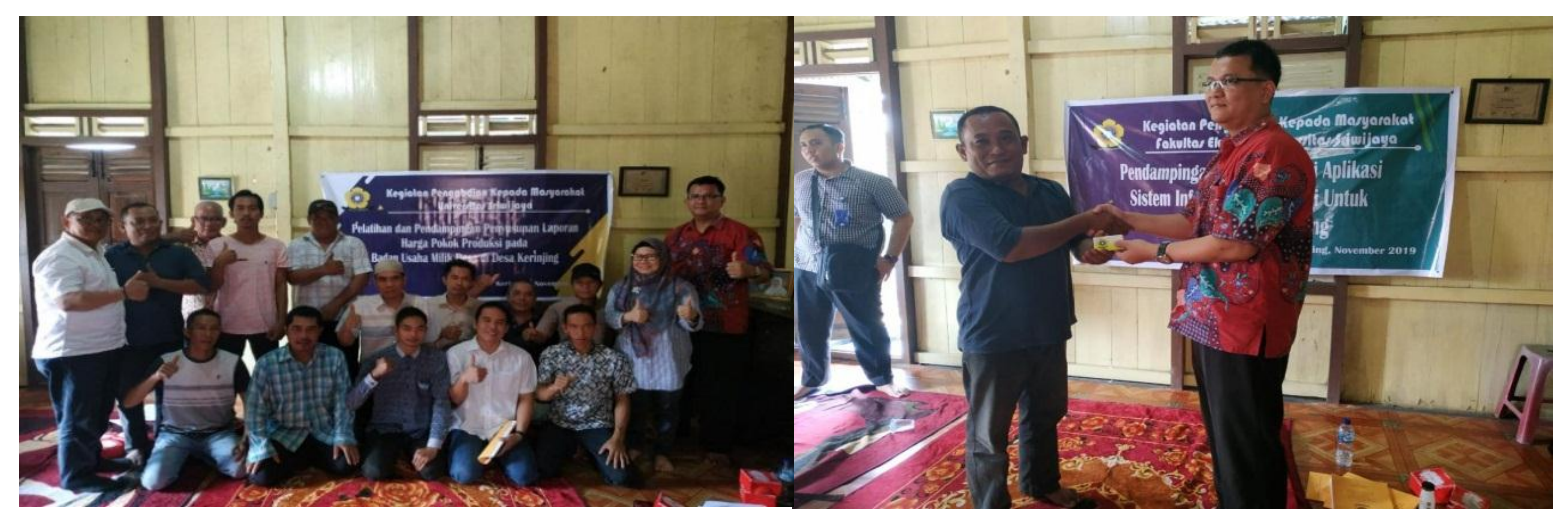

Gambar 2. Foto Bersama Peserta dan Serah Terima Aplikasi Software

Dengan demikian warga pelaku UMKM dapat memahami dengan lebih jelas hal-hal yang masih belum dimengerti. Tim pengabdian juga memberikan software yang berisi aplikasi sederhana dalam pelaporan keuangan yang dapat dimanfaatkan oleh warga Desa Kerinjing khususnya pelaku UMKM dan Bumdes.

\section{SIMPULAN}

Kegiatan pendampingan implementasi aplikasi system informasi akuntansi pada UMKM di Desa Kerinjing, Ogan Ilir dapat bermanfaat memberikan kontribusi dalam pengembangan bisnis Usaha Mikro Kecil Menengah di Desa Kerinjing Ogan Ilir khususnya dalam optimalisasi kinerja system informasi akuntansi. Output dari kegiatan ini adalah wujudnya aplikasi system informasi akuntansi yang dapat diimplementasikan UMKM di Desa Kerinjing, Ogan Ilir.

\section{UCAPAN TERIMA KASIH (ACKNOWLEDGMENTS)}

Ucapkan terimakasih kami sampaikan kepada Fakultas Ekonomi Universitas Sriwijaya yang telah mendanai kegiatan ini dan warga Desa Kerinjing yang begitu antusias dalam menerima kehadiran kami.

\section{REFERENSI}

Abor, J. \& Bokpin, G.A. (2010). Investment opportunities, corporate finance, and dividend payout policy: Evidence from emerging markets. Studies in Economics and Finance, 27 (3), 180-194. https://doi.org/10.1108/10867371011060018.

Almilia, L.S., \& Briliantien, I. (2007). Faktor-faktor yang Mempengaruhi Kinerja Sistem Informasi Akuntansi pada Bank Umum Pemerintah di Wilayah Surabaya dan Sidoarjo. Jurnal Akuntansi. Surabaya : STIE Perbananas.

Apriani, D., Robiani, B., Yulianita, A., Mukhlis, M., \& Sukanto, S. (2021). Mewaspadai Investasi Bodong dan Arisan Berantai Online di Desa Kerinjing Kecamatan Tanjung Raja Kabupaten Ogan Ilir. Sricommerce: Journal of Sriwijaya Community Services, 2(1), 1-6. doi:https://doi.org/10.29259/jscs.v2i1.23.

Dyer, J. C., \& McHugh, A. J. (1975). The Timeliness of the Australian Annual Report. Journal of Accounting Research, 13(2), 204-219. https://doi.org/10.2307/2490361.

Farhan, M., Novriansa, A., Kalsum, U., \& Mukhtaruddin, M. (2020). Pengenalan Akuntansi bagi Usaha Mikro Kecil dan Menengah (UMKM) di Desa Kota Daro, Kabupaten Ogan Ilir. Sricommerce: Journal of Sriwijaya Community Services, 1(1), 47-54. doi:https://doi.org/10.29259/jscs.v1i1.11.

Gelinas, J.U., Dull, R. B., \& Wheeler, P.R. (2012). Accounting Information Systems. South Western: Cengage Learning.

Hakiki, A., Rahmawati, M., \& Novriansa, A. (2020). Penggunaan Sistem Informasi Akuntansi untuk Usaha Mikro Kecil dan Menengah (UMKM) di Desa Kota Daro, Kabupaten Ogan Ilir. 
Sricommerce: Journal of Sriwijaya Community Services, 1(1), 55-62.

doi:https://doi.org/10.29259/jscs.v1i1.12.

Hidayat, I. P., \& Fadillah, A.R. (2012). Pengaruh Penyaluran Kredit Usaha Mikro Kecil Menengah

(UMKM) dan Pendapatan Operasional terhadap Laba operasional, http://imanph.files.wordpress.com, 11 Juni 2012.

Hubeis. M. (2009). Prospek Usaha Kecil dalam wadah Inkubator Bisnis, Ghalia Indonesia, Jakarta.

Ikatan Akuntan Indonesia. (2015). Standar Akuntansi Keuangan. Jakarta: Salemba Empat. Keputusan Presiden RI No. 99 tahun 1998.

Muhindo, A., Mzuza, M. K., \& Zhou, J. (2014). Impact of Accounting Information Systems on Profitability of Small Scale Businesses: A Case of Kampala City in Uganda. International Journal of Academic Research in Management (IJARM). 3 (2), 185-192.

Romney, M. B., \& Steinbart, P.J. (2009), Accounting Information System. Elevent Edition, Prentice Hall International, New Jersey.

Romney, M. B., \& Steinbart, P.J. (2013). Accounting Information System. Nineth Edition. Pearson Education, Inc.

Sekaran, U. (2000). Metodologi Penelitian Untuk Bisnis. Jakarta : Salemba Empat.

Srimindarti, C., \& Puspitasari, E. (2012). Kinerja Sistem Informasi Akuntansi (SIA) ditinjau dari Kepuasan Pemakai dan Pemkaian SIA yang dipengaruhi oleh partisipasi, kemampuan, pelatihan dan pendidikan pemakai SIA. Pekan IImiah, Dosen FEB-UKSW. 517-530.

Stair. R., \& Reynolds. G. (2009). Fundamentals of Information Systems. USA: Thomson. Surya, R.A.S. (2012). Akuntansi Keuangan Versi IFRS. Yogyakarta: Graha IImu.

Undang - undang Nomor 9 Tahun 1995 tentang Usaha Kecil.

Undang-Undang Republik Indonesia Nomor 20 Tahun 2008 Tentang Usaha Mikro, Kecil, dan Menengah. 